\title{
Peripheral Administration of a Humanized Anti-PrP Antibody Blocks Alzheimer's Disease A $\beta$ Synaptotoxicity
}

\author{
Igor Klyubin, ${ }^{1 \star}$ Andrew J. Nicoll, ${ }^{2 \star}$ Azadeh Khalili-Shirazi, ${ }^{2 \star}$ Michael Farmer, ${ }^{2}$ Stephanie Canning, ${ }^{2}$ Alexandra Mably, ${ }^{3}$ \\ Jacqueline Linehan, ${ }^{2}$ Alexander Brown, ${ }^{4}$ Madeleine Wakeling, ${ }^{2}$ Sebastian Brandner, ${ }^{2}$ Dominic M. Walsh, ${ }^{3}$ \\ Michael J. Rowan, ${ }^{1}$ and John Collinge ${ }^{2}$ \\ ${ }^{1}$ Department of Pharmacology and Therapeutics and Institute of Neuroscience, Trinity College, Dublin 2, Republic of Ireland, ${ }^{2}$ Medical Research Council \\ Prion Unit and Department of Neurodegenerative Disease, UCL Institute of Neurology, London WC1N 3BG, United Kingdom, ${ }^{3}$ Laboratory for \\ Neurodegenerative Research, Center for Neurologic Diseases, Brigham \& Women’s Hospital, Harvard Institute of Medicine, Boston, Massachusetts 02115, \\ and ${ }^{4}$ Biotherapeutics Group, Medical Research Council Technology, Mill Hill, London, United Kingdom NW7 1AD
}

Alzheimer's disease $(\mathrm{AD})$ is associated with pathological assembly states of amyloid- $\beta$ protein $(\mathrm{A} \beta)$. A $\beta$-related synaptotoxicity can be blocked by anti-prion protein (PrP) antibodies, potentially allowing therapeutic targeting of this aspect of AD neuropathogenesis. Here, we show that intravascular administration of a high-affinity humanized anti-PrP antibody to rats can prevent the plasticity-disrupting effects induced by exposure to soluble AD brain extract. These results provide an in vivo proof of principle for such a therapeutic strategy.

Key words: Alzheimer's; drug discovery; immunotherapy; long-term potentiation; prion

\section{Introduction}

Alzheimer's disease (AD) presents one of the greatest healthcare and economic challenges globally, but no effective therapy to halt or delay disease progression has been developed. Rather than being a single disease entity, AD may be considered a clinicopathological syndrome with multiple interacting genetic and environmental factors involved in its onset and progression. Aggregation of the amyloid- $\beta$ protein $(\mathrm{A} \beta)$ is believed to be central, with water-soluble nonfibrillar assemblies closely linked to memory impairment (Benilova et al., 2012). Only certain synthetic and cell-derived $\mathrm{A} \beta$ preparations are synaptotoxic in vitro at patho-

Received Aug. 16, 2013; revised Feb. 3, 2014; accepted March 1, 2014.

Author contributions: I.K., A.J.N., J.L., M.W., S.B., D.M.W., M.J.R., and J.C. designed research; I.K., A.J.N., A.K.-S., M.F., S.C., A.J.M., and S.B. performed research; A.J.N., A.K.-S., S.C., A.B., and J.C. contributed unpublished reagents/ analytic tools; I.K., A.J.N., A.K.-S., M.F., S.C., A.J.M., M.W., S.B., D.M.W., and M.J.R. analyzed data; I.K., A.J.N., A.K.-S., J.L., M.W., S.B., D.M.W., M.J.R., and J.C. wrote the paper.

This work was funded by the UK Medical Research Council (J.C.), Science Foundation Ireland and the European Union Framework 7 Project MEMOLOAD (M.J.R.), and the Health Research Board of Ireland (I.K.). We thank P. Seubert and D. Schenk for 2G3 and 21F12; Ray Young for preparation of figures; Angela Richard-Londt and Sarah Lyall for assistance with histology; Mark Batchelor for preparation of recombinant protein; Patrick Hextall, Simon Mead, and Caroline Potter for helpful discussion; and Werner Frings for leading the cynomolgus macaques PK study.

J.C. is a shareholder and director of D-Gen Limited, an academic spin-out company in the field of prion diagnosis, decontamination, and therapeutics. D.M.W. is a member of the scientific advisory board of Cognition Therapeutics, Inc., and is a consultant to Eisai $C_{0 .,}$ Ltd. The remaining authors declare no competing financial interests.

*I.K., A.J.N., and A.K.-S. contributed equally to this work.

This article is freely available online through the J Neurosci Author Open Choice option.

Correspondence should be addressed to either of the following: Michael J. Rowan, Department of Pharmacology and Therapeutics and Institute of Neuroscience, Trinity College, Biotechnology Building, Dublin 2, Republic of Ireland, E-mail: mrowan@tcd.ie; or John Collinge, Medical Research Council Prion Unit and Department of Neurodegenerative Disease, UCL Institute of Neurology, Queen Square, London WC1N 3BG, United Kingdom, E-mail: j.collinge@prion.ucl.ac.uk.

DOI:10.1523/JNEUROSCI.3526-13.2014

Copyright (c) 2014 Klyubin et al.

This is an Open Access article distributed under the terms of the Creative Commons Attribution License (http://creativecommons.org/licenses/by/3.0), which permits unrestricted use, distribution and reproduction in any medium provided that the original work is properly attributed. physiologically pertinent low nanomolar concentrations (Benilova et al., 2012). Importantly, soluble extract from AD brain contains potent toxic $A \beta$ assemblies that can rapidly disrupt hippocampal long-term potentiation (LTP; Shankar et al., 2008), a form of synaptic plasticity implicated in memory and learning (Bliss and Collingridge, 1993). Although different assembly forms of $\mathrm{A} \beta$ may exert toxicity by different mechanisms (Benilova et al., 2012), it is known that prion protein $(\mathrm{PrP})$ is required for at least some aspects of $\mathrm{A} \beta$ toxicity (Laurén et al., 2009; Barry et al., 2011; Freir et al., 2011). Targeting PrP, which has been investigated extensively as a strategy for treating prion disease, is attractive because both constitutive knock-out of $\operatorname{PrP}$ expression and ablation of neuronal PrP expression in the adult mouse are without major phenotypes (Nicoll and Collinge, 2009). The murine monoclonal antibodies 6D11 (Laurén et al., 2009), Fab-D13 (Barry et al., 2011), and ICSM35 (Freir et al., 2011), which bind directly to the $\mathrm{A} \beta$-binding site on $\operatorname{PrP}$ (Laurén et al., 2009), block A $\beta$ induced inhibition of LTP, as does ICSM18, which binds to helix-1 of PrP (Freir et al., 2011). 6D11 was shown to reverse behavioral deficits when administered intraperitoneally into an amyloid precursor protein/presenilin-1 mutant mouse model of $\mathrm{AD}$ (Chung et al., 2010), but it is uncertain whether this involved a direct action in the nervous system or how the $\mathrm{A} \beta$ assemblies in transgenic mouse models relate to those found in human $\mathrm{AD}$ brain. It has been suggested that cross-linking of PrP by antibodies that interact close to the $\mathrm{A} \beta$-binding site on $\mathrm{PrP}$ triggers neuronal apoptosis in vivo (Solforosi et al., 2004), although we were unable to confirm this (Klohn et al., 2012). Furthermore, crosslinking via this epitope of PrP has been proposed as a cause of PrP-dependent A $\beta$ toxicity (Bate and Williams, 2011) and this region has been suggested to be involved with $\operatorname{PrP}$ function and binding interactions (Béland and Roucou, 2012). In contrast, antibodies that bind to only helix- 1 of $\mathrm{PrP}$ are consistently innoc- 
A

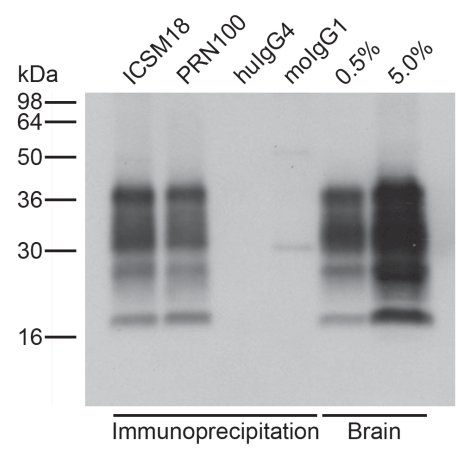

B

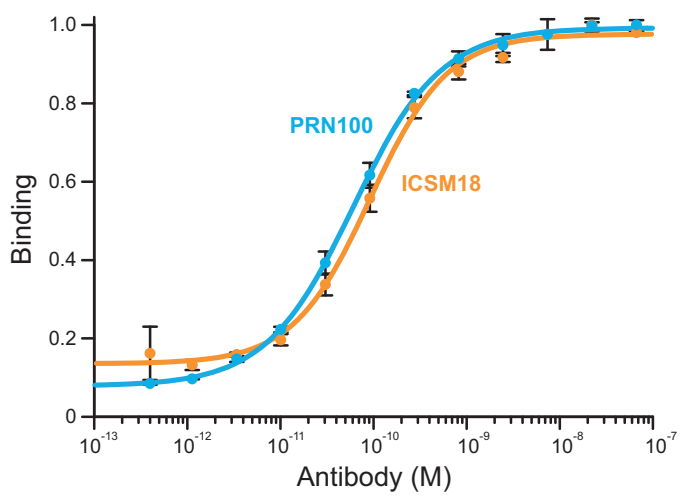

Figure 1. The humanized monoclonal antibody PRN100 displays similar PrP-binding properties to its murine parent, ICSM18. $\boldsymbol{A}$, Both ICSM18 and PRN100 efficiently immunoprecipitate all major PrP glycoforms from human brain homogenate. $\boldsymbol{B}$, Representative binding isotherm of PRN100 (blue) and ICSM18 (orange) show a similar high-affinity interaction to surface-bound recombinant murine $\operatorname{PrP}_{91-231}$.

uous, even on direct injection into the hippocampus at $1 \mathrm{mg} / \mathrm{ml}$ (Solforosi et al., 2004; Klohn et al., 2012; Ohsawa et al., 2013), which produces a local concentration of up to $6 \mu \mathrm{M}-\sim 10,000$ fold higher than the dissociation constant (Antonyuk et al., 2009). Because clinical therapeutic use would preferentially involve dosing of antibody via intravenous or subcutaneous routes, we sought to determine whether peripheral administration of a humanized anti-PrP antibody could effectively target $\operatorname{PrP}-\mathrm{A} \beta$ interactions and prevent the disruptive effects of toxic $\mathrm{AD}$ brain $\mathrm{A} \beta$ assemblies in vivo (Roettger et al., 2013).

\section{Materials and Methods}

Antibody development. Antibody humanization was performed with the complementarity-determining region grafting method (Jones et al., 1986) and human frameworks were chosen on the basis of their conservation of key framework residues (Williams et al., 2010). Candidate humanized antibodies were then expressed as IgG1 molecules and retention of binding to antigen was confirmed by ELISA. The lead candidate was cloned in an IgG4 format selected for reduced effector function before progressing to cell line development using a proprietary glutamine synthetase expression system (Lonza Biologics). The construct encodes a Ser to Pro mutation at the interheavy chain disulfide bond to strengthen the hinge region and reduce the formation of half antibody (Angal et al., 1993). PRN100 was manufactured from the master cell bank at the $200 \mathrm{~L}$ scale and purified using a two-step chromatography process to generate highly purified antibody ( $99.3 \%$ by HPLC).

Immunoprecipitation and Western blotting of $\mathrm{PrP}$ from normal human brains. Human brain samples were obtained and used under ethical approval from the National Research Ethics Service (03/133), homogenized to $10 \% \mathrm{w} / \mathrm{v}$ in Dulbecco's $\mathrm{Mg}^{2+} / \mathrm{Ca}^{2+}$-free PBS (Invitrogen) with a Dounce homogenizer, and used for immunoprecipitation and Western blotting, as described previously (Khalili-Shirazi et al., 2005), with ICSM18 (D-Gen) as the detection antibody.

Protein expression and purification. Constructs of human PrP were expressed (Jackson et al., 1999) and purified (Zahn et al., 1997) as described previously. Protein quality was confirmed by SDS-PAGE, MALDI-TOF mass spectrometry, and circular dichroism spectroscopy.

Antibody affinity ELISA. ELISA plates were coated with recombinant murine $\mathrm{PrP}_{91-231}(2.5 \mu \mathrm{g} / \mathrm{ml})$ in 50 mm sodium carbonate buffer, $\mathrm{pH}$ 9.6, washed with PBS $(0.05 \%$ Tween 20$)$, and blocked with Superblock T20 (Thermo Scientific). PRN100 or ICSM18 diluted in PBS (0.1\% bovine $\gamma$ globulin) were incubated and washed with PBS (0.05\% Tween 20$)$ before detecting with species-specific HRP conjugated antibodies (Sigma) in PBST $(0.05 \%$ Tween 20$)$ coupled to a 3,3',5,5'-tetramethylbenzidine
(BD Biosciences) substrate. Absorbance at 450 $\mathrm{nm}$ was read using a Tecan Sunrise plate.

Preparation of human AD brain extract for electrophysiology. Brain was prepared as described previously (Freir et al., 2011). Brain tissue from a 92-year-old woman with a history of dementia and confirmed AD pathology was obtained and used in accordance with local Institutional Review Board guidelines. Human temporal cortex was homogenized in 1:5 (w/v) ice-cold Tris-buffered saline (TBS), $\mathrm{pH} 7.4$, containing protease inhibitors with 20 passes of a Dounce homogenizer (Fisher Scientific). The homogenized samples were centrifuged at $175,000 \times g$ for $30 \mathrm{~min}$ at $4^{\circ} \mathrm{C}$ and the supernatant (TBS extract) was removed. TBS extract was desalted and $A \beta$-rich fractions were pooled and the $\mathrm{A} \beta$ content estimated using a sensitive immunoprecipitation/Western blot protocol. Known amounts of synthetic $\mathrm{A} \beta_{1-42}$ were electrophoresed on the same gel to allow quantification of $\mathrm{A} \beta$ in the TBS extract. After transfer, membranes were immunoblotted with a combination of the monoclonal antibodies $2 \mathrm{G} 3$ and 21F12 (1:1000 dilution). Goat anti-mouse antibody (1: 2500 dilution) conjugated to infrared dye was used to visualize $\mathrm{A} \beta$ bands using a LI-COR Odyssey Near Infrared Imaging system.

Electrophysiology. In vivo electrophysiology was performed as described previously (Klyubin et al., 2008; Freir et al., 2011). Animal experiments were licensed by the Department of Health and Children, Ireland. Adult male Wistar rats were anesthetized with urethane $(1.5 \mathrm{~g} / \mathrm{kg}$, i.p. $)$. Single pathway recordings of field EPSPs were made from the stratum radiatum in the CA1 area of the dorsal hippocampus in response to stimulation of the ipsilateral Schaffer collateral/commissural pathways. Test EPSPs were evoked at a frequency of $0.033 \mathrm{~Hz}$ and at a stimulation intensity adjusted to give an EPSP amplitude of $50 \%$ of maximum. The high-frequency stimulation (HFS) protocol for inducing LTP consisted of 10 trains of 20 stimuli, interstimulus interval of $5 \mathrm{~ms}$, and an intertrain interval of $2 \mathrm{~s}$. The intensity was increased to give an EPSP of $75 \%$ of maximum amplitude during the HFS. LTP is expressed as the mean \pm SEM percentage of baseline field EPSP amplitude recorded over at least a $30 \mathrm{~min}$ baseline period. Similar results were obtained when EPSP slope rather than amplitude was measured.

For statistical analysis, EPSP amplitudes were grouped into $10 \mathrm{~min}$ epochs. Standard one-way ANOVA was used to compare the magnitude of LTP between multiple groups, followed by post hoc Tukey's tests. Unpaired Student's $t$ tests were used for two-group comparisons. $p<$ 0.05 was considered statistically significant.

To inject samples into the rat brain, a cannula was implanted in the lateral cerebral ventricle (coordinates: $1 \mathrm{~mm}$ lateral to the midline and 4 $\mathrm{mm}$ below the surface of the dura) just before electrode implantation. Injections (10-8 $\mu$ l over 6-8 min) were made via a Hamilton syringe connected to the internal cannula. Control human myeloma IgG4 $\kappa$ antibody was obtained from Sigma (catalog \#I4639). An interval of $1.5 \mathrm{~h}$ or more was left between the implantation procedure and the intracardiac injection of $0.6 \mathrm{ml}$ of PRN100 or buffer $(25 \mathrm{~mm} \mathrm{NaAc}, 75 \mathrm{~mm} \mathrm{NaCl}$, $\mathrm{pH}$ 5.5) under urethane anesthesia. Intracardiac injections were made via a 23 ga needle inserted directly into rat heart.

Histology and imaging. Brains were fixed in $10 \%$ buffered formal saline, immersed in $98 \%$ formic acid for $1 \mathrm{~h}$, and paraffin wax embedded after formalin postfixation. Sections of $4 \mu \mathrm{m}$ nominal thickness were stained with $\mathrm{H} \& \mathrm{E}$ to visualize basic structures and immunostained for additional markers (microglia: Iba-1 antibody, Wako; myelinated fiber tracts: SMI-94R, Covance; cleaved Caspase-3: Asp175, Cell Signaling Technology) on Ventana Discovery XT automated biomarker platforms using EZ Prep Solution and antigen retrieval with Cell Conditioning Solution Plus (Ventana). Immunostainings were visualized using the DAB Map Detection Kit (Ventana). Sections were counterstained with hematoxylin and coverslipped on a Leica CV5030 coverslipper. Slides were digitized on a Leica SCN400 slide scanner, visualized on the Slide- 

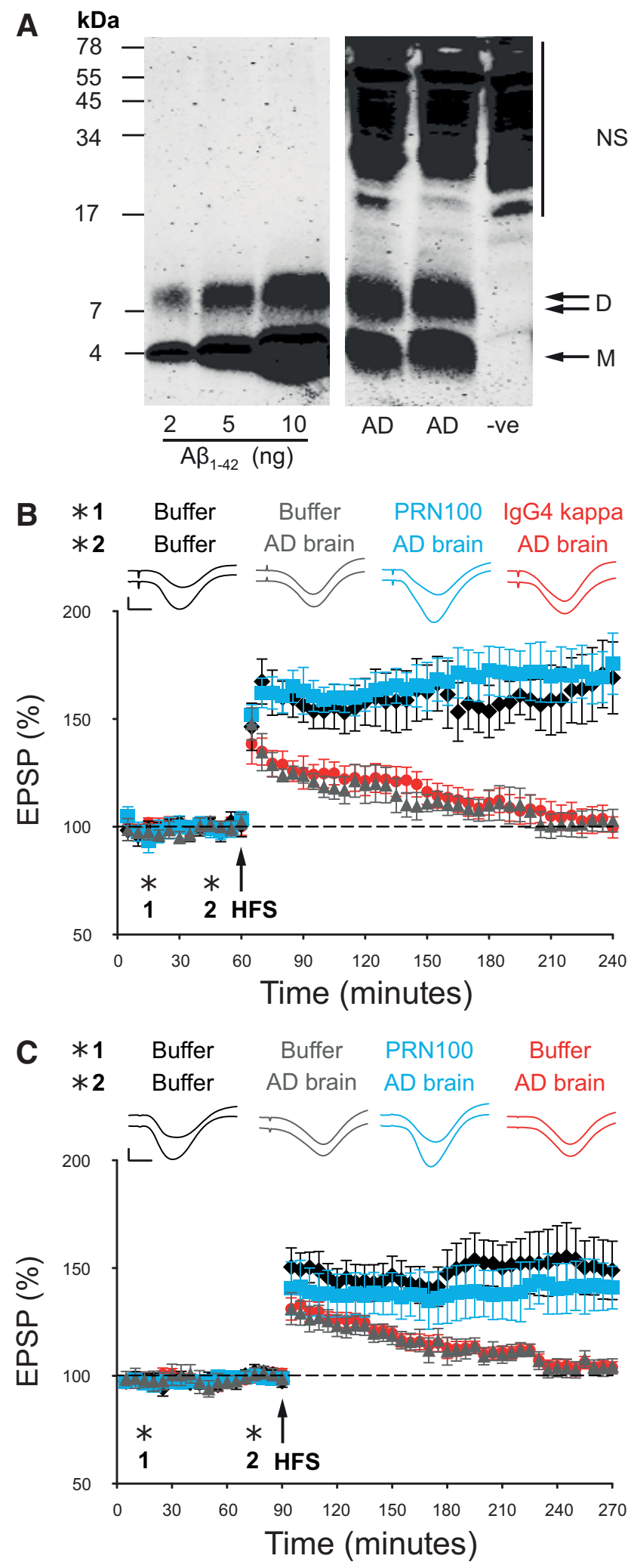

Figure 2. PRN100 blocks soluble AD brain $(\boldsymbol{A})$ extract-induced inhibition of hippocampal LTP when infused centrally $(\boldsymbol{B})$ or peripherally $(\boldsymbol{C})$. $\boldsymbol{A}$, Soluble AD brain extract contained $3.8 \mathrm{ng} / \mathrm{ml}$ $A \beta$ monomers and $2.4 \mathrm{ng} / \mathrm{ml} A \beta$ dimers as measured by sensitive immunoprecipitation/Western blotting technique. Bands migrating at a molecular weight consistent for $A \beta$ monomer $(M)$ and SDS-stable dimer (D) are seen in the AD TBS extract. Synthetic $A \beta_{1-42}$ standards loaded for protein quantification are shown on the left. Nonspecific immunoreactive bands (NS) migrating $>17 \mathrm{kDa}$ can also be seen in the negative control lane ( - ve). $\boldsymbol{B}$, Synaptic field potentials were recorded in vivo from the CA1 area of anesthetized male Wistar rats. In buffer-injected rats
Path Digital Image Hub. Regions of interest were captured with a screen capture tool, followed by arranging captures in Adobe Photoshop.

Collection of plasma and CSF. A cisternal puncture method was used for CSF sampling under anesthesia. After exposing the atlanto-occipital membrane, CSF was collected from the cisterna magna. Whole blood was obtained from the anesthetized animal by decapitation, collected into Eppendorf tubes containing $\sim 30 \mu \mathrm{l}$ of $0.5 \mathrm{~m}$ EDTA, and inverted several times before being centrifuged for $10 \mathrm{~min}$ at $1000 \times \mathrm{g}$. Plasma and CSF were stored frozen at $-80^{\circ} \mathrm{C}$.

PRN100 detection ELISA. ELISA plates were coated with recombinant murine $\operatorname{PrP}_{91-231}(2.5 \mu \mathrm{g} / \mathrm{ml})$ in $50 \mathrm{~mm}$ sodium carbonate buffer, $\mathrm{pH} 9.6$, washed with PBS $(0.05 \%$ Tween 20$)$, and blocked with Superblock T20 (Thermo Scientific). Sera (1:2000) and CSF (1:5) diluted in PBS (2\% milk powder) were incubated and washed with PBS $(0.05 \%$ Tween 20$)$ before detecting with anti-human Fc-specific HRP conjugated antibody (1: $25,000)$ in PBST $\left(0.05 \%\right.$ Tween 20 ; Sigma) coupled to a $3,3^{\prime}, 5,5^{\prime}$ tetramethylbenzidine (BD Biosciences) substrate. Absorbance at $450 \mathrm{~nm}$ was read using a Tecan Sunrise plate reader with concentrations of PRN100 calculated relative to purified standard curves diluted in equivalent buffer and control fluid.

Evans blue assay. Anesthetized rats were infused with a $2 \%$ solution of Evans blue ( $2 \mathrm{ml} / \mathrm{kg}$, intracardiac). Five minutes after the treatment, the animals were killed by intracardiac perfusion with PBS and brains were harvested and preserved in formaldehyde.

\section{Results}

\section{PRN100 retains key binding properties of ICMS18}

As part of a program to develop a monoclonal anti-PrP antibody for passive immunotherapy of prion infection and disease, we have developed a fully humanized version of ICSM18, a highaffinity mouse monoclonal antibody effective in treating murine prion infection (White et al., 2003; Freir et al., 2011; Klohn et al., 2012). An $\mathrm{IgG}_{4}$ isotype was engineered as a clinical candidate to minimize unwanted $F_{c}$ effector function and was designated PRN100. Both ICSM18 and PRN100 recognized, and successfully immunoprecipitated, all isoforms of PrP found in human brain (Fig. 1A). This suggests that PRN100 has the potential to target the same PrP species as ICSM18 in vivo and could block the $\mathrm{A} \beta$-induced disruption of LTP caused by PrP-dependent assemblies. PRN100 bound avidly to high-density recombinant murine $\mathrm{PrP}$ with an apparent dissociation constant $(50 \pm 10 \mathrm{pM})$ comparable to that $(40 \pm 20 \mathrm{pM})$ for ICSM18 (Fig. $1 B, n=4)$. Therefore, the efficacious dose of PRN100 should be similar to ICSM18, but with reduced probability of $\mathrm{F}_{\mathrm{c}}$ effector-related toxicity. These data indicate that PRN100 has retained key PrPbinding properties of ICSM18.

\footnotetext{
$\leftarrow$

(1: first injection $10 \mu$ l, i.c.v.; 2: second injection $8 \mu$ l 30 min later) HFS 15 min after the second injection triggered persistent and stable LTP (black diamonds, $169 \pm 17 \%$ at $3 \mathrm{~h}$ after tetanus, $n=5)$. In contrast, significant inhibition of LTP was observed after injection of $8 \mu \mathrm{l}$ of A $\beta$ containing brain extract in animals preinjected with buffer (gray triangles, $103 \pm 5 \%, n=5$, $p<0.05$ ) or $30 \mu \mathrm{g}$ of an IgG4 isotype control antibody (IgG4kappa, red circles, $100 \pm 5 \%, n=$ $5, p<0.05)$. However, injection of PRN100 (30 $\mu \mathrm{g}) 30$ min before injection of soluble AD brain extract prevented the inhibition of LTP (blue squares, $176 \pm 14 \%, n=5$ ). C, In buffer-injected rats (1: first injection $600 \mu$, intracardiac; 2: second injection $8 \mu$ l, i.c.v. 30 min later) HFS 15 min after the second injection triggered persistent and stable LTP (black diamonds, $149 \pm 14 \%$ at $3 \mathrm{~h}$ after tetanus, $n=6$ ). Intracardiac injection of buffer followed by intracerebroventricular infusion of AD brain fully inhibited LTP (red circles, $104 \pm 3 \%, n=6, p<0.05$ ). Intracardiac injection of $6 \mathrm{mg}$ of PRN100 reversed this effect (blue squares, $141 \pm 10 \%, n=5$ ), showing that peripheral administration of PRN100 blocks AD brain extract-derived $A \beta$ synaptotoxicity. The PRN100 measurements were conducted blind (gray triangles vs blue squares). Insets show representative EPSP traces. Top trace corresponds to $5 \mathrm{~min}$ before HFS and the bottom to $3 \mathrm{~h}$ after HFS. Horizontal bar, $5 \mathrm{~ms}$; vertical bar, $1 \mathrm{mV}$.
} 
PRN100

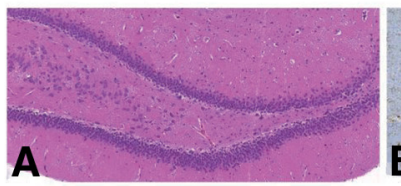

H\&E

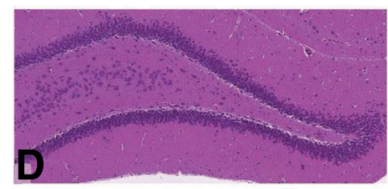

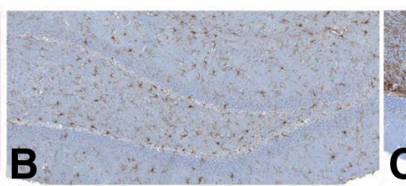

Microglia (Iba-1)

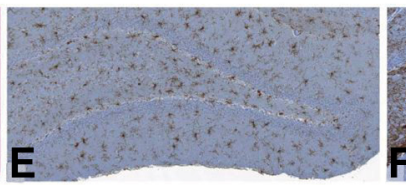

Control AD/ IgG

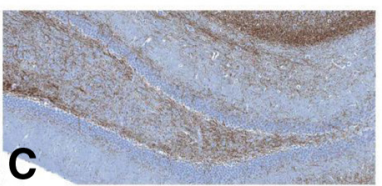

Myelin Basic Protein

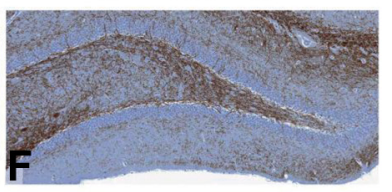

-

Figure 3. ICV injection of PRN100 did not cause overt neuronal damage up to $4 \mathrm{~h}$ after administration. Shown is the immunohistochemical analysis of hippocampi from PRN100-injected $(\boldsymbol{A}-\boldsymbol{C})$ and isotype control-injected $(\boldsymbol{D}-\boldsymbol{F})$ rats. H\&E or immunohistochemical (Iba-1 or SMI-94) staining $(\boldsymbol{A}, \boldsymbol{D})$ shows no evident neuronal damage, demyelination $(\boldsymbol{C}, \boldsymbol{F})$, or microglial activation in PRN-100 treated rats $(\boldsymbol{B})$ compared with isotype control-treated animals $(\boldsymbol{E})$. Scale bar, $100 \mu \mathrm{M}$.

\section{Peripheral infusion of PRN100 blocks AD brain-induced inhibition of LTP}

We then tested whether PRN100 could prevent the synaptic plasticity-disrupting action of soluble AD brain extract in live rats, as we have described for ICSM18 (Freir et al., 2011). After intracerebroventricular injection of buffer alone, a robust LTP could be evoked using an HFS protocol. However, injection of a water-soluble $\mathrm{AD}$ brain extract rich in $\mathrm{A} \beta$ species, including SDSstable dimers (Fig. 2A), fully inhibited LTP within 3 h (Fig. $2 B$ ). Importantly, brain extract immunodepleted of $A \beta$ did not inhibit LTP ( $n=5$, data not shown). When $30 \mu \mathrm{g}$ of PRN100 was injected 30 min before the AD brain extract, robust LTP was also observed, indicating that PRN100 can block the disruptive effect of $\mathrm{A} \beta$ found in $\mathrm{AD}$ brain. An isotype control human IgG4 (IgG4 kappa purified from human myeloma plasma) failed to prevent the toxic effect. Neuropathological analysis showed no signs of PRN100-induced neuronal apoptosis, microglial activation, or demyelination (Fig. 3).

For peripherally administered PRN100 to be therapeutically active against either established neuroinvasive prion infection or $\mathrm{AD}$, it will need to cross the blood-brain barrier (BBB) and target $\mathrm{PrP}$ in relevant regions of the brain such as the hippocampus (Roettger et al., 2013). Pharmacokinetic studies are ongoing to determine the dosing regime required to obtain therapeutic levels in the CNS, which will require sufficient dosing to overcome target-mediated drug disposition, because $\mathrm{PrP}$ is also widely expressed in the periphery (Linden et al., 2008). However, as a proof of principle, we injected a single $6 \mathrm{mg}$ dose of PRN100 via the intracardiac route $1 \mathrm{~h}$ before intracerebroventricular injection of $\mathrm{AD}$ brain extract and monitored the effect on LTP induction. Remarkably, such intravascular infusion of PRN100 also prevented inhibition of LTP, suggesting that PRN100 was able to cross the $\mathrm{BBB}$ and target $\mathrm{PrP}$ (Fig. $2 \mathrm{C}$ ). As with direct intracerebroventricular injection, there was no histologically detectable neurotoxicity (Fig. 4). We collected blood and CSF from the rats used in the study and quantified PRN100 concentrations. ELISA detection, performed in a blinded fashion, correctly identified all rats with PRN100 in their blood and CSF. Concentrations of $1.4 \pm 0.7 \mu \mathrm{M}$ PRN100 $(210 \pm 110 \mu \mathrm{g} / \mathrm{ml})$ were detected in serum and $1.7 \pm 3.4 \mathrm{nM}(0.26 \pm 0.51 \mu \mathrm{g} / \mathrm{ml})$ concentrations were found in CSF (equivalent to $\sim 0.1 \%$ of that detected in blood), confirming that sufficient PRN100 can enter the CNS even after a single dose $(n=5)$ to achieve a pharmacodynamic effect. A non-BBB penetrant dye, Evans blue (Kozler and Pokorný, 2003), was injected via the intracardiac route $2 \mathrm{~h}$ after electrode implantation to test for BBB integrity and was not detected at the electrode site or elsewhere in the brain (data not shown).

\section{Discussion}

The potential for anti-PrP antibodies to prevent $\mathrm{A} \beta$ synaptotoxicity in $\mathrm{AD}$ has been established previously. However, no fully humanized anti-PrP antibody potentially applicable to $\mathrm{AD}$ patients has been reported. We show that PRN100 retains key properties of the parent murine antibody, ICSM18, and can block A $\beta$ induced inhibition of LTP when injected directly into the brain without inducing overt acute neurotoxicity. It would be interesting to determine whether PRN100 can also reverse behavioral deficits seen in $\mathrm{AD}$ rodent models, although maintaining long-term dosing may be difficult if antidrug antibodies develop and the PrP dependence of toxicity varies between models and at different time points. Furthermore, it was unknown whether such antibodies could cross the BBB in sufficient quantities to target PrP in disease-relevant areas of the brain such as the hippocampus. We have now shown that, after a single injection into the rat blood stream, PRN100 can indeed reach therapeutically active concentrations even when subnanomolar concentrations are detected in the CSF. We could not reliably visualize PRN100 in fixed rat brain parenchyma using immunohistochemistry due to diffuse background staining. The concentrations observed in the CSF are well below any reported toxic concentrations (Solforosi et al., 2004; Sonati et al., 2013).

Recently, Sonati et al. (2013) have reported acute toxicity associated with some, but not other, anti-PrP antibodies from their POM series (Polymenidou et al., 2008). Toxicity was observed principally in organotypic slice cultures from, and limited in vivo studies in, transgenic mice with high levels of PrP overexpression (Sonati et al., 2013). There was an inconsistent association with epitope. Toxicity was seen at very high local concentrations after direct injection into brain parenchyma and is of questionable relevance to any likely human therapeutic approach.

Although all therapeutics will be toxic at sufficiently high acute or chronic dosing, formal safety studies have been performed as part of the evaluation of PRN100 before an application to UK regulators for a clinical trial authorization (in the primary indication for which PRN100 was developed, Creutzfeldt-Jakob disease [CJD]). Subject to an acceptable risk: benefit evaluation, it is envisaged that first-in-human studies would be in patients with sporadic CJD, a uniformly fatal condition with a mean clinical duration of 4 months. A single ascending dose safety study has been performed in cynomolgus macaques (Covance) to underpin this study and showed no clinical or pathological evidence of CNS toxicity at intravenous doses up to and including $200 \mathrm{mg} / \mathrm{kg}$ (achieving peak serum concentrations in excess of $5 \mathrm{mg} / \mathrm{ml}$ ), well in excess of those proposed for initial human studies.

Several fully penetrant inherited forms of prion disease are caused by single amino acid substitutions in the $A \beta$-binding epitope and many are found throughout the $C$ terminus of the structured domain, but none are known in the helix-1 region (Collinge, 2001). Therefore, using antibodies exclusively target- 

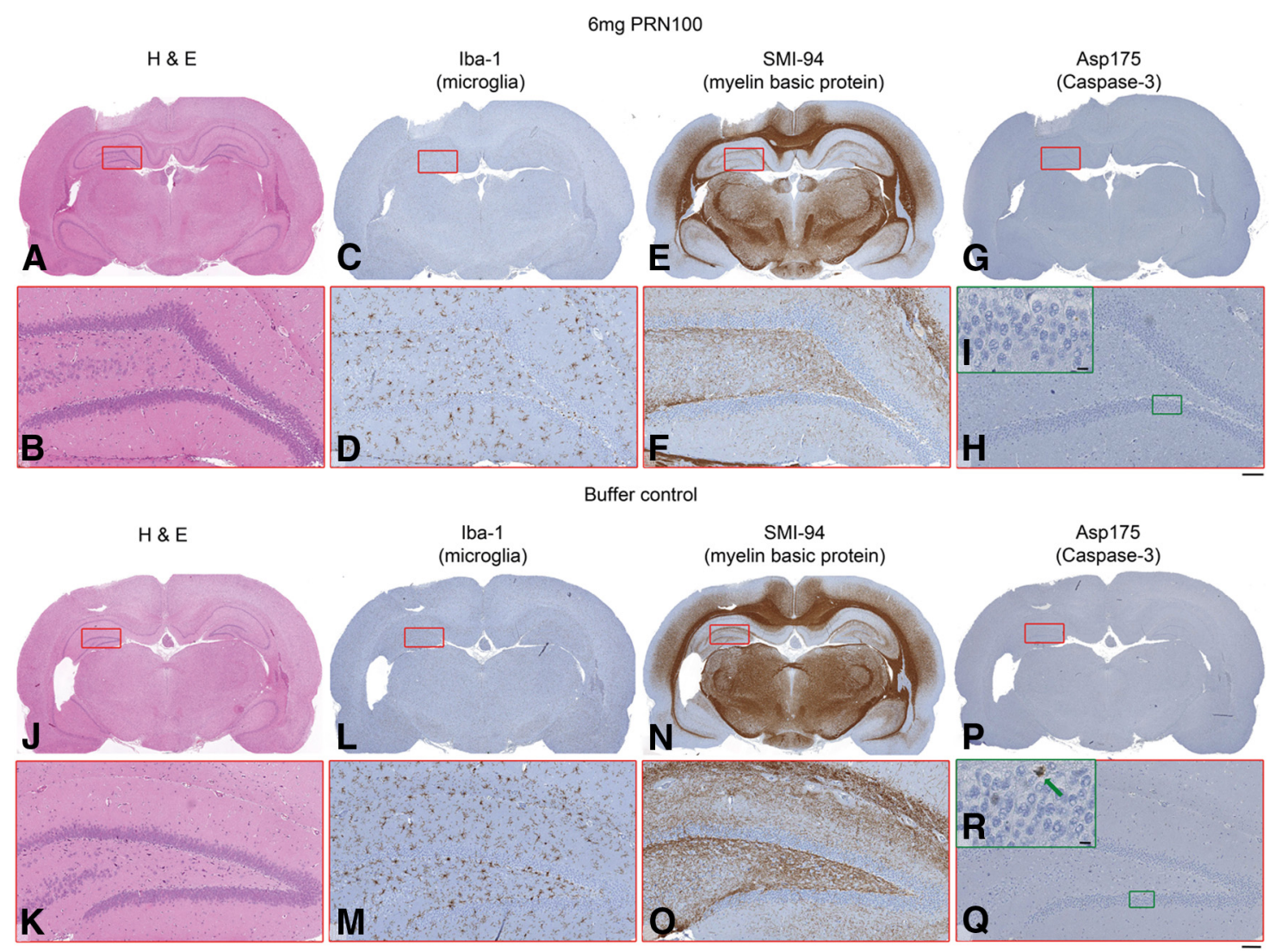

Figure 4. Intracardiac injection of PRN100 did not cause overt neuronal damage up to $14 \mathrm{~h}$ after administration. Shown is the immunohistochemical analysis of whole brains from PRN100injected $(\boldsymbol{A}-\boldsymbol{I})$ and buffer control-injected $(\boldsymbol{J}-\boldsymbol{R})$ rats. H\&E staining $(\boldsymbol{A}, \boldsymbol{B}, \boldsymbol{J}, \boldsymbol{K})$ shows no sign of neuronal damage or demyelination $(\boldsymbol{E}, \boldsymbol{F}, \boldsymbol{N}, \boldsymbol{0})$. There is no increase in microglia activation in PRN-100 rats $(\boldsymbol{C}, \boldsymbol{D})$ compared with buffer control-injected animals $(\boldsymbol{L}, \boldsymbol{M})$ or cleaved Caspase-3 (green arrow; $\mathbf{G}-\boldsymbol{I}$ vs $\boldsymbol{P}-\boldsymbol{R}$ ). Scale bars, $100 \mu \mathrm{m}$ for red zoomed panels and $10 \mu \mathrm{m}$ for green zoomed panels.

ing helix-1 of PrP may be a superior therapeutic strategy to reduce PrP-dependent $\mathrm{A} \beta$ toxicity rather than using antibodies with nonlinear epitopes or those that directly target the $\mathrm{A} \beta$ binding site itself.

Should proposed clinical studies of PRN100 in prion disease (a rapidly fatal, untreatable condition) demonstrate adequate safety characteristics and pharmacokinetic parameters in humans, it may be appropriate to consider experimental medicine studies in early AD to determine whether PRN100 administration has acute effects on memory and learning, which would suggest a potential role for blocking $\operatorname{PrP}-\mathrm{A} \beta$ interactions in $\mathrm{AD}$ therapeutics.

\section{References}

Angal S, King DJ, Bodmer MW, Turner A, Lawson AD, Roberts G, Pedley B, Adair JR (1993) A single amino-acid substitution abolishes the heterogeneity of chimeric mouse/human (Igg4) antibody. Mol Immunol 30: 105-108. CrossRef Medline

Antonyuk SV, Trevitt CR, Strange RW, Jackson GS, Sangar D, Batchelor M, Cooper S, Fraser C, Jones S, Georgiou T, Khalili-Shirazi A, Clarke AR, Hasnain SS, Collinge J (2009) Crystal structure of human prion protein bound to a therapeutic antibody. Proc Natl Acad Sci U S A 106:25542558. CrossRef Medline

Barry AE, Klyubin I, Mc Donald JM, Mably AJ, Farrell MA, Scott M, Walsh DM, Rowan MJ (2011) Alzheimer's disease brain-derived amyloid- $\beta$ mediated inhibition of LTP in vivo Is prevented by immunotargeting cellular prion protein. J Neurosci 31:7259-7263. CrossRef Medline

Bate C, Williams A (2011) Amyloid- $\beta$-induced synapse damage is mediated via cross-linkage of cellular prion proteins. J Biol Chem 286:3795537963. CrossRef Medline
Béland M, Roucou X (2012) The prion protein unstructured N-terminal region is a broad-spectrum molecular sensor with diverse and contrasting potential functions. J Neurochem 120:853-868. CrossRef Medline

Benilova I, Karran E, De Strooper B (2012) The toxic A $\beta$ oligomer and Alzheimer's disease: an emperor in need of clothes. Nat Neurosci 15:349357. CrossRef Medline

Bliss TV, Collingridge GL (1993) A synaptic model of memory: long-term potentiation in the hippocampus. Nature 361:31-39. CrossRef Medline

Chung E, Ji Y, Sun Y, Kascsak RJ, Kascsak RB, Mehta PD, Strittmatter SM, Wisniewski $\mathrm{T}$ (2010) Anti-PrP ${ }^{\mathrm{C}}$ monoclonal antibody infusion as a novel treatment for cognitive deficits in an Alzheimer's disease model mouse. BMC Neurosci 11:130. CrossRef Medline

Collinge J (2001) Prion diseases of humans and animals: their causes and molecular basis. Annu Rev Neurosci 24:519-550. CrossRef Medline

Freir DB, Nicoll AJ, Klyubin I, Panico S, Mc Donald JM, Risse E, Asante EA, Farrow MA, Sessions RB, Saibil HR, Clarke AR, Rowan MJ, Walsh DM, Collinge J (2011) Interaction between prion protein and toxic amyloid- $\beta$ assemblies can be therapeutically targeted at multiple sites. Nat Commun 2:336. CrossRef Medline

Jackson GS, Hill AF, Joseph C, Hosszu L, Power A, Waltho JP, Clarke AR, Collinge J. (1999) Multiple folding pathways for heterologously expressed human prion protein. Biochim Biophys Acta 1431:1-13. CrossRef Medline

Jones PT, Dear PH, Foote J, Neuberger MS, Winter G (1986) Replacing the complementarity-determining regions in a human-antibody with those from a mouse. Nature 321:522-525. CrossRef Medline

Khalili-Shirazi A, Summers L, Linehan J, Mallinson G, Anstee D, Hawke S, Jackson GS, Collinge J (2005) PrP glycoforms are associated in a strainspecific ratio in native $\mathrm{PrP}^{\mathrm{Sc}}$. J Gen Virol 86:2635-2644. CrossRef Medline

Klöhn PC, Farmer M, Linehan JM, O’Malley C, Fernandez de Marco M, Taylor W, Farrow M, Khalili-Shirazi A, Brandner S, Collinge J (2012) 
PrP antibodies do not trigger mouse hippocampal neuron apoptosis. Science 335:52. CrossRef Medline

Klyubin I, Betts V, Welzel AT, Blennow K, Zetterberg H, Wallin A, Lemere CA, Cullen WK, Peng Y, Wisniewski T, Selkoe DJ, Anwyl R, Walsh DM, Rowan MJ (2008) Amyloid- $\beta$ protein dimer-containing human CSF disrupts synaptic plasticity: prevention by systemic passive immunization. J Neurosci 28:4231-4237. CrossRef Medline

Kozler P, Pokorný J (2003) Altered blood-brain barrier permeability and its effect on the distribution of Evans blue and sodium fluorescein in the rat brain applied by intracarotid injection. Physiol Res 52:607-614. Medline

Laurén J, Gimbel DA, Nygaard HB, Gilbert JW, Strittmatter SM (2009) Cellular prion protein mediates impairment of synaptic plasticity by amyloid- $\beta$ oligomers. Nature 457:1128-1132. CrossRef Medline

Linden R, Martins VR, Prado MA, Cammarota M, Izquierdo I, Brentani RR (2008) Physiology of the prion protein. Physiol Rev 88:673-728. CrossRef Medline

Nicoll AJ, Collinge J (2009) Preventing prion pathogenicity by targeting the cellular prion protein. Infect Disord Drug Targets 9:48-57. CrossRef Medline

Ohsawa N, Song CH, Suzuki A, Furuoka H, Hasebe R, Horiuchi M (2013) Therapeutic effect of peripheral administration of an anti-prion protein antibody on mice infected with prions. Microbiol Immunol 57:288-297. CrossRef Medline

Polymenidou M, Moos R, Scott M, Sigurdson C, Shi YZ, Yajima B, HafnerBratkovic I, Jerala R, Hornemann S, Wuthrich K, Bellon A, Vey M, Garen G, James MN, Kav N, Aguzzi A (2008) The POM monoclonals: A comprehensive set of antibodies to non-overlapping prion protein epitopes. PLoS One 3:e3872. CrossRef Medline
Roettger Y, Du Y, Bacher M, Zerr I, Dodel R, Bach JP (2013) Immunotherapy in prion disease. Nat Rev Neurol 9:98-105. CrossRef Medline

Shankar GM, Li S, Mehta TH, Garcia-Munoz A, Shepardson NE, Smith I, Brett FM, Farrell MA, Rowan MJ, Lemere CA, Regan CM, Walsh DM, Sabatini BL, Selkoe DJ (2008) Amyloid- $\beta$ protein dimers isolated directly from Alzheimer's brains impair synaptic plasticity and memory. Nat Med 14:837-842. CrossRef Medline

Solforosi L, Criado JR, McGavern DB, Wirz S, Sánchez-Alavez M, Sugama S, DeGiorgio LA, Volpe BT, Wiseman E, Abalos G, Masliah E, Gilden D, Oldstone MB, Conti B, Williamson RA (2004) Cross-linking cellular prion protein triggers neuronal apoptosis in vivo. Science 303:15141516. CrossRef Medline

Sonati T, Reimann RR, Falsig J, Baral PK, O'Connor T, Hornemann S, Yaganoglu S, Li B, Herrmann US, Wieland B, Swayampakula M, Rahman MH, Das D, Kav N, Riek R, Liberski PP, James MN, Aguzzi A (2013) The toxicity of antiprion antibodies is mediated by the flexible tail of the prion protein. Nature 501:102-106. CrossRef Medline

White AR, Enever P, Tayebi M, Mushens R, Linehan J, Brandner S, Anstee D, Collinge J, Hawke S (2003) Monoclonal antibodies inhibit prion replication and delay the development of prion disease. Nature 422:80-83. CrossRef Medline

Williams DG, Matthews DJ, Jones T (2010) Humanising antibodies by CDR grafting. In: Antibody engineering (Roland Kontermann SD, ed), pp 319-339. Berlin: Springer-Verlag.

Zahn R, von Schroetter C, Wüthrich K (1997) Human prion proteins expressed in Escherichia coli and purified by high-affinity column refolding. FEBS Lett 417:400-404. CrossRef Medline 